\title{
Characteristics of Organophosphate Ester Formation during Smoking
}

\author{
Haruki Shimazu ${ }^{1}$ \\ ${ }^{1}$ School of Science and Engineering, Kindai University, Osaka, Japan \\ Correspondence: Haruki Shimazu, School of Science and Engineering, Kindai University, Osaka, 577 8502, Japan. \\ Tel: 81-6-4307-3559. E-mail: hshimazu@civileng.kindai.ac.jp
}

Received: May 30, 2018

Accepted: June 26, $2018 \quad$ Online Published: September 29, 2018

doi:10.5539/ep.v7n2p32

URL: https://doi.org/10.5539/ep.v7n2p32

\begin{abstract}
This study examines the occurrence of organophosphate esters (OPEs) in cigarettes and sidestream cigarette smoke and to see the OPE formation characteristics during smoking. All seven OPEs in both gas and particulate phases were measured in sidestream cigarette smoke for four brands of cigarettes. Tributyl phosphate (TBP), tris(2-butoxyethyl) phosphate (TBEP), tris(2-chloroethyl) phosphate (TCEP), and triphenyl phosphate (TPP) were found frequently. Median total OPE increases in the air samples during smoking were $56.2 \mathrm{ng}$ per cigarette for gas-phase OPEs and $2360 \mathrm{ng}$ per cigarette for particulate-phase OPEs. TBP and TCEP could be absorbed to particles in air more readily than alkans as seen from the correlation line between gas-particle partition coefficients $(\mathrm{Kp})$ and the subcooled liquid vapor pressures $\left(\mathrm{PL}^{\circ}\right)$ for alkans. Furthermore, TBP was determined in the cigarettes. Median total OPE decreases in the cigarette samples during smoking were $1200 \mathrm{ng}$ per cigarette. The combustion reaction increased TBP and TBEP levels in cigarettes, and particulate-phase TBEP in air appeared to influence the production of TBP, TCEP, and TPP. TBP and TBEP in cigarettes likely affect the production of TBP, TBEP, TCEP, and TPP in air during smoking.
\end{abstract}

Keywords: cigarette, sidestream cigarette smoke, organophosphate esters, gas-particle partitioning coefficient, formation characteristics

\section{Introduction}

Organophosphate esters (OPEs) are a group of chemicals widely used as organic plasticizers, flame retardants, hydraulic fluids, and other industrial products. The use of OPEs as replacements for polybrominated diphenyl ethers and other brominated flame retardants has recently increased (Brommer et al., 2012; Van der Veen et al., 2012). Global consumption of OPEs was 186000 tons in 2001 and icreased to 292000 tons in 2011 (Marklund et al., 2005; Townsend Solutions, 2012). In this situation, OPEs have been detected in a variety of environments (Kawagoshi et al., 1999; Andresen et al., 2004; Chung et al., 2009; Fries et al., 2011; Shimazu et al., 2013; Salamova et al., 2014; Lai et al., 2015).

Some of the OPEs show carcinogenic and/or neurotoxic properties. The World Health Organization has listed tris(2-chloroethyl) phosphate (TCEP) and tris(1,3-dichloro-2-propyl) phosphate (TDCPP) as carcinogenic compounds (WHO, 1998). Tris(2-butoxyethyl) phosphate (TBEP) and tris(2-chloroisopropylethyl) phosphate are also suspected to be carcinogenic (WHO, 1998; WHO, 2000). TBEP, tributyl phosphate (TBP), TCEP, and triphenyl phosphate (TPP) are considered neurotoxins (WHO, 1991a; WHO, 1991b; WHO, 1998; WHO, 2000). Triethyl phosphate (TEP) is considered a weak enzyme inhibitor (Gosselin et al, 1984). The use of OPEs has therefore been restricted in multiple countries. TCEP is shown in the Candidate List of primary concern substances issued by the European Union (European Chemicals Agency, 2009). The use of TCEP, TDCPP, and tris(1-chloro-2-propyl) phosphate as flame retardants in toys and children's products is prohibited by the US (TÜV Rheinland Group, 2013).

Shimazu (2016) has reported particulate-phase OPEs in cigarette smoke. Little information, however, is available on OPEs in sidestream cigarette smoke, which mainly affects passive smokers. To evaluate the health effects of OPEs in cigarette smoke, OPE partition between the gas and particulate phases should be elucidated. This study examined the occurrence of OPEs in gas and particulate phases and their gas/particulate partitioning in sidestream cigarette smoke.

In addition, Shimazu (2016) has reported OPEs in the cigarette body prior to smoking. To assess OPE emissions from cigarettes and their formation characteristics during smoking, this study also examined the occurrence of 
OPEs in cigarettes and cigarette butts.

\section{Materials and Methods}

\subsection{Samples}

Four brands of cigarettes were investigated in this study. Tar and nicotine contents were 6-19 mg and 0.5-1.4 mg per cigarette, respectively. OPE concentrations in air and cigarette samples before and after cigarettes had been smoked were measured.

Four air samples were collected before and after cigarettes of brands A-D had been smoked. The air sampling room was $2.5 \mathrm{~m}$ high, $5.3 \mathrm{~m}$ long, and $5.0 \mathrm{~m}$ wide, with a volume of approximately $66 \mathrm{~m}^{3}$. Each air sample was collected prior to smoking using a high-volume air sampler (HV-500R; Sibata Scientific Technology Ltd., Souka, Japan) over a period of $1 \mathrm{~h}$ at a flow rate of $400 \mathrm{~L} / \mathrm{min}$, giving a sampling volume of $24 \mathrm{~m}^{3}$. Particulate matter was collected on a quartz fiber filter (QR-100; Advantec, Tokyo, Japan). Particles with diameters of $0.3 \mu \mathrm{m}$ were taken by the filter with a minimum particle collection efficiency of $99.99 \%$ when the air was passed through the sampler at a velocity of $5 \mathrm{~cm} / \mathrm{s}$. Gas-phase OPEs were collected on two polyurethane foam plugs (080130-0941A; Sibata Scientific Technology Ltd.) After the initial air samples had been collected, the door and windows of the sampling room were left open for approximately $1 \mathrm{~h}$. The door and windows were then closed, and two cigarettes were smoked in the room. Sidestream smoke samples were collected using the high-volume air sampler over a period of $2.75 \mathrm{~h}$ at a flow rate of $400 \mathrm{~L} / \mathrm{min}$, giving a sampling volume of $66 \mathrm{~m}^{3}$. Particulate-phase OPEs were collected on a quartz fiber filter, and gas-phase OPEs were collected on two polyurethane foam plugs. The filters and polyurethane foam plugs were then analyzed as described below.

OPE levels in cigarettes before and after smoking were also determined. Cigarette samples (before smoking) and butt samples (after smoking) were analyzed. The arithmetic means of the weights of the four brands of cigarettes before smoking $(\mathrm{n}=4)$ were $0.107-0.181 \mathrm{~g}$ for the filters and $0.525-0.586 \mathrm{~g}$ for the leaves. Cigarette weights after smoking $(\mathrm{n}=4)$ were $0.158-0.285 \mathrm{~g}$ for the filters and $0.075-0.078 \mathrm{~g}$ for the leaves. Whole filters and leaves of cigarette samples were analyzed as described below. After each brand was smoked, whole filters and leaves of the butt samples were also analyzed.

\subsection{OPES}

The target compounds were the seven OPEs listed in Table 1. These OPEs have been frequently detected in multiple environmental media and are known to exert toxic effects. The standard of OPEs were purchased from Tokyo Chemical Industry Co., Ltd. (Tokyo, Japan) and diluted with acetone and hexane to produce calibration standards.

Table 1. OPEs measured in this study

\begin{tabular}{lll}
\hline OPEs & Abbreviations & CAS No. \\
\hline Tris(2-butoxyethyl) phosphate & TBEP & $78-51-3$ \\
Tributyl phosphate & TBP & $126-73-8$ \\
Tris(2-chloroethyl) phosphate & TCEP & $115-96-8$ \\
Tris(1,3-dichloro-2-propyl) phosphate & TDCPP & $13674-78-8$ \\
Tris(2-ethylhexyl) phosphate & TEHP & $78-42-2$ \\
Triethyl phosphate & TEP & $78-40-0$ \\
Triphenyl phosphate & TPP & $115-86-6$ \\
\hline
\end{tabular}

Note. The abbreviations are used in this study.

\subsection{Analytical Methods and Instruments}

Each quartz fiber filter was weighed with an electronic balance before and after smoking. Each filter that had been used to sample air after smoking was cut into 16 sections. All sections of the filter were set in $260-\mathrm{mL}$ bottles and extracted with $100 \mathrm{~mL}$ of hexane for pesticide residue and polychlorinated biphenyl analysis by Wako Pure Chemical Industries, Ltd. (Tokyo, Japan) for $15 \mathrm{~min}$ in an ultrasonic bath. The extract was concentrated to $3 \mathrm{~mL}$ with a rotary evaporator, and passed through a disposable filter (Whatman Puradisc $25 \mathrm{TF}$; GE Healthcare Life Sciences, Maidstone, UK). The extract was then concentrated to $1.5 \mathrm{~mL}$ under nitrogen flow. 
Finally, $200 \mu \mathrm{L}$ of internal standard mixture and hexane were added to bring the volume to $2 \mathrm{~mL}$.

Two polyurethane foam plugs were used in each experiment. Each polyurethane foam plug that had been used to sample air after smoking was cut into 16 sections. All sections were set in $260-\mathrm{mL}$ bottles and extracted with 220 $\mathrm{mL}$ of hexane for $15 \mathrm{~min}$ in an ultrasonic bath. The separate extracts of the two foam plugs were each concentrated to $3 \mathrm{~mL}$ with a rotary evaporator and then mixed. Next, the extract was passed through a disposable filter and concentrated to $1.5 \mathrm{~mL}$ under nitrogen flow. Finally, $200 \mu \mathrm{L}$ of internal standard mixture and hexane were added to bring the volume to $2 \mathrm{~mL}$.

Cigarette filters and leaves before and after smoking were analyzed. Each sample was weighed, placed into a cellulose extraction thimble (Whatman high-performance cellulose extraction thimbles; GE Healthcare Life Sciences), and extracted with $100 \mathrm{~mL}$ of hexane for $15 \mathrm{~min}$ in an ultrasonic bath. The extract was concentrated to $3 \mathrm{~mL}$ using a rotary evaporator and passed through a disposable filter device. Next, the extract was concentrated to $1.5 \mathrm{~mL}$ under nitrogen flow. Finally, $200 \mu \mathrm{L}$ of internal standard mixture and hexane were added to bring the volume to $2 \mathrm{~mL}$.

OPEs in the extracts were injected in splitless mode in an HP-5MS capillary column (30-m long, 0.25-mm i.d., $0.25-\mu \mathrm{m}$ film thickness; Agilent Technologies, Santa Clara, CA, USA) with a gas chromatograph-mass spectrometer (5975B inert XL E/CI MSD; Agilent Technologies). The gas chromatograph was used with a sample volume of $2 \mu \mathrm{L}$ and an injection port temperature of $250^{\circ} \mathrm{C}$. The oven temperature program started at $70^{\circ} \mathrm{C}$ (held for $1.5 \mathrm{~min}$ ), and was then increased by $20^{\circ} \mathrm{C} / \mathrm{min}$ to $180^{\circ} \mathrm{C}$, followed by an increase of $5^{\circ} \mathrm{C} / \mathrm{min}$ to $280^{\circ} \mathrm{C}$ (held for $1 \mathrm{~min}$ ). Helium was used as the carrier gas. The mass spectrometer was operated in electron impact ionization mode and an electron energy of $70 \mathrm{eV}$. After each analyte was identified using two representative fragment ions, it was quantified using the largest fragment ion. Quantification was performed with an internal standard calibration method using standards containing the seven OPEs shown in Table 1 and three deuterated polycyclic aromatic hydrocarbons (525 Fortification Solution, 48230-U; Supelco, Bellefonte, PA, USA).

Total suspended particulate concentration $\left(\mu \mathrm{g} / \mathrm{m}^{3}\right)$ was defined as the difference between the weight of the quartz fiber filters before and after air sampling divided by $24 \mathrm{~m}^{3}$ for a sample collected before cigarettes had been smoked or $66 \mathrm{~m}^{3}$ for a sample collected after cigarettes had been smoked.

\section{Results and Discussion}

\subsection{Gas-phase and Particulate OPEs in Air Samples}

Three gas-phase OPEs were detected in the air samples before cigarettes had been smoked (Table 2). Gas-phase TBP was detected in seven of the 16 samples; the highest concentration detected was $3.10 \mathrm{ng} / \mathrm{m}^{3}$. The total gas-phase OPE concentrations before smoking peaked at $9.72 \mathrm{ng} / \mathrm{m}^{3}$.

All seven gas-phase OPEs were detected in the air samples after cigarettes had been smoked (Table 2). TBP and TCEP were detected in 11 of the 16 samples. TPP was detected in nine samples. The median concentration of TCEP, which was the most abundant gas-phase OPE measured after smoking, was $2.10 \mathrm{ng} / \mathrm{m}^{3}$ (range: Not detected to $3.67 \mathrm{ng} / \mathrm{m}^{3}$ ). The median of the total gas-phase OPE concentrations after smoking was $4.77 \mathrm{ng} / \mathrm{m}^{3}$ (range: Not detected to $16.6 \mathrm{ng} / \mathrm{m}^{3}$ ). The concentrations of gas-phase OPEs in the air samples were higher after smoking. The medians of these concentration differences before and after smoking were $0.01 \mathrm{ng} / \mathrm{m}^{3}$ for TBP, $2.10 \mathrm{ng} / \mathrm{m}^{3}$ for TCEP, and $0.11 \mathrm{ng} / \mathrm{m}^{3}$ for TPP.

Three particulate-phase OPEs were detected in the air samples before cigarettes had been smoked (Table 3). TCEP was detected in 11 of the 16 samples. TBP was detected in seven samples, and tris(2-ethylhexyl) phosphate (TEHP) was detected in one sample. The median concentration of TCEP, which was the largest particulate-phase OPE measured before smoking, was $2.35 \mathrm{ng} / \mathrm{m}^{3}$ (range: Not detected to $6.57 \mathrm{ng} / \mathrm{m}^{3}$ ). The highest particulate-phase OPE concentration before smoking was $10.8 \mathrm{ng} / \mathrm{m}^{3}$.

All seven particulate-phase OPEs were detected in the air samples after cigarettes had been smoked (Table 3). TBP was detected in all 16 samples. Other OPEs were detected in 15 samples (TBEP and TCEP), 13 samples (TPP), seven samples (TEHP), and one sample (TDCPP and TEP). The median concentration of TBEP, which was the largest particulate-phase OPE measured after smoking, was $64.7 \mathrm{ng} / \mathrm{m}^{3}$ (range: Not detected to 103 $\mathrm{ng} / \mathrm{m}^{3}$ ). The median of the total particulate-phase OPE concentrations after smoking was $74.2 \mathrm{ng} / \mathrm{m}^{3}$ (range: $7.50-115 \mathrm{ng} / \mathrm{m}^{3}$ ). The concentrations of particulate-phase OPEs in the air samples were higher after smoking. The medians of these concentration differences before and after smoking were $64.7 \mathrm{ng} / \mathrm{m}^{3}$ for TBEP, $4.48 \mathrm{ng} / \mathrm{m}^{3}$ for TBP, $0.68 \mathrm{ng} / \mathrm{m}^{3}$ for TCEP, and $0.97 \mathrm{ng} / \mathrm{m}^{3}$ for TPP.

The median concentration of suspended particulate matter before smoking was $21 \mu \mathrm{g} / \mathrm{m}^{3}$ (range: $8-33 \mu \mathrm{g} / \mathrm{m}^{3}$ ). 
After smoking, the median was $104 \mu \mathrm{g} / \mathrm{m}^{3}$ (range: $73-152 \mu \mathrm{g} / \mathrm{m}^{3}$ ).

Table 2. Gas-phase OPEs in air samples

\begin{tabular}{|c|c|c|c|c|c|c|c|c|}
\hline & \multicolumn{2}{|c|}{ Brand A } & \multicolumn{2}{|c|}{ Brand B } & \multicolumn{2}{|c|}{ Brand $\mathrm{C}$} & \multicolumn{2}{|c|}{ Brand D } \\
\hline & Before & After & Before & After & Before & After & Before & After \\
\hline \multirow{2}{*}{ TBEP } & $\mathrm{ND}(0 / 4)$ & $0.84(2 / 4)$ & $\mathrm{ND}(0 / 4)$ & $0.71(2 / 4)$ & $\mathrm{ND}(0 / 4)$ & $\mathrm{ND}(0 / 4)$ & $\mathrm{ND}(0 / 4)$ & $\mathrm{ND}(0 / 4)$ \\
\hline & [ND] & [ND-2.69] & [ND] & [ND-5.27] & [ND] & [ND] & [ND] & [ND] \\
\hline \multirow{2}{*}{ TBP } & $\mathrm{ND}(0 / 4)$ & $7.37(4 / 4)$ & $0.98(3 / 4)$ & ND (0/4) & ND (1/4) & $2.07(3 / 4)$ & $1.63(3 / 4)$ & $1.67(4 / 4)$ \\
\hline & [ND] & [2.34-7.83] & [ND-2.61] & [ND] & [ND-3.10] & [ND-4.35] & [ND-2.32] & {$[1.42-2.22]$} \\
\hline \multirow{2}{*}{ TCEP } & ND $(0 / 4)$ & $2.19(4 / 4)$ & ND (1/4) & $2.55(4 / 4)$ & ND (0/4) & ND $(0 / 4)$ & ND (0/4) & $2.26(3 / 4)$ \\
\hline & {$[\mathrm{ND}]$} & {$[1.15-2.76]$} & [ND-0.48] & [1.92-3.67] & {$[\mathrm{ND}]$} & {$[\mathrm{ND}]$} & {$[\mathrm{ND}]$} & [ND-2.83] \\
\hline \multirow{2}{*}{ TDCPP } & ND (0/4) & $\mathrm{ND}(1 / 4)$ & ND (0/4) & $\mathrm{ND}(0 / 4)$ & ND $(0 / 4)$ & ND $(0 / 4)$ & $\mathrm{ND}(0 / 4)$ & $\mathrm{ND}(0 / 4)$ \\
\hline & [ND] & [ND-3.70] & {$[\mathrm{ND}]$} & {$[\mathrm{ND}]$} & [ND] & {$[\mathrm{ND}]$} & [ND] & [ND] \\
\hline \multirow{2}{*}{ TEHP } & ND (0/4) & $0.80(2 / 4)$ & ND (0/4) & $2.23(4 / 4)$ & $\mathrm{ND}(0 / 4)$ & ND (0/4) & $\mathrm{ND}(0 / 4)$ & $\mathrm{ND}(0 / 4)$ \\
\hline & [ND] & [ND-1.92] & {$[\mathrm{ND}]$} & {$[0.43-2.23]$} & {$[\mathrm{ND}]$} & {$[\mathrm{ND}]$} & {$[\mathrm{ND}]$} & {$[\mathrm{ND}]$} \\
\hline \multirow{2}{*}{ TEP } & ND (0/4) & $\mathrm{ND}(1 / 4)$ & ND (0/4) & $\mathrm{ND}(0 / 4)$ & ND (0/4) & ND (0/4) & $\mathrm{ND}(0 / 4)$ & ND (0/4) \\
\hline & [ND] & [ND-0.56] & [ND] & [ND] & [ND] & [ND] & [ND] & [ND] \\
\hline \multirow{2}{*}{ TPP } & $\mathrm{ND}(0 / 4)$ & $1.59(4 / 4)$ & $\mathrm{ND}(1 / 4)$ & $2.30(4 / 4)$ & $\mathrm{ND}(0 / 4)$ & $\mathrm{ND}(1 / 4)$ & ND $(0 / 4)$ & $\mathrm{ND}(0 / 4)$ \\
\hline & {$[\mathrm{ND}]$} & {$[0.23-2.15]$} & [ND-6.63] & [2.11-2.49] & {$[\mathrm{ND}]$} & [ND-0.53] & {$[\mathrm{ND}]$} & {$[\mathrm{ND}]$} \\
\hline
\end{tabular}

Note. The upper values show median concentration (detection rate) and the lower values show [concentration range]. All units are $\mathrm{ng} / \mathrm{m}^{3}$. ND means Not detected.

Table 3. Particulate-phase OPEs in air samples

\begin{tabular}{|c|c|c|c|c|c|c|c|c|}
\hline & \multicolumn{2}{|c|}{ Brand A } & \multicolumn{2}{|c|}{ Brand B } & \multicolumn{2}{|c|}{ Brand C } & \multicolumn{2}{|c|}{ Brand D } \\
\hline & Before & After & Before & After & Before & After & Before & After \\
\hline \multirow{2}{*}{ TBEP } & $\mathrm{ND}(0 / 4)$ & $59.2(4 / 4)$ & $\mathrm{ND}(0 / 4)$ & $78.8(4 / 4)$ & $\mathrm{ND}(0 / 4)$ & $64.1(4 / 4)$ & $\mathrm{ND}(0 / 4)$ & $34.8(3 / 4)$ \\
\hline & [ND] & {$[41.4-83.7]$} & {$[\mathrm{ND}]$} & [67.9-103] & {$[\mathrm{ND}]$} & {$[34.5-78.4]$} & {$[\mathrm{ND}]$} & [ND-62.9] \\
\hline \multirow{2}{*}{ TBP } & $1.55(3 / 4)$ & $6.72(4 / 4)$ & $0.32(2 / 4)$ & $6.69(4 / 4)$ & $\mathrm{ND}(1 / 4)$ & $3.71(4 / 4)$ & $\mathrm{ND}(1 / 4)$ & $3.87(4 / 4)$ \\
\hline & [ND-7.71] & {$[5.12-7.16]$} & [ND-4.09] & {$[5.91-8.53]$} & [ND-0.86] & {$[3.02-5.20]$} & [ND-0.82] & [1.86-5.37] \\
\hline \multirow{2}{*}{ TCEP } & $4.57(4 / 4)$ & $4.09(4 / 4)$ & $2.62(4 / 4)$ & $3.55(4 / 4)$ & $1.91(3 / 4)$ & $3.27(4 / 4)$ & $\mathrm{ND}(0 / 4)$ & $2.70(3 / 4)$ \\
\hline & {$[3.12-6.57]$} & [3.79-4.92] & {$[0.97-3.07]$} & {$[2.96-3.76]$} & [ND-3.03] & {$[2.66-3.62]$} & [ND] & [ND-2.94] \\
\hline \multirow{2}{*}{ TDCPP } & ND (0/4) & $\mathrm{ND}(1 / 4)$ & $\mathrm{ND}(0 / 4)$ & $\mathrm{ND}(0 / 4)$ & $\mathrm{ND}(0 / 4)$ & $\mathrm{ND}(0 / 4)$ & $\mathrm{ND}(0 / 4)$ & $\mathrm{ND}(0 / 4)$ \\
\hline & {$[\mathrm{ND}]$} & [ND-3.91] & {$[\mathrm{ND}]$} & {$[\mathrm{ND}]$} & [ND] & [ND] & {$[\mathrm{ND}]$} & [ND] \\
\hline \multirow{2}{*}{ TEHP } & $\mathrm{ND}(0 / 4)$ & $1.45(4 / 4)$ & $\mathrm{ND}(0 / 4)$ & $0.74(2 / 4)$ & $\mathrm{ND}(1 / 4)$ & ND (1/4) & $\mathrm{ND}(0 / 4)$ & $\mathrm{ND}(0 / 4)$ \\
\hline & {$[\mathrm{ND}]$} & [0.47-1.99] & {$[\mathrm{ND}]$} & [ND-2.19] & [ND-1.88] & [ND-0.59] & [ND] & [ND] \\
\hline \multirow{2}{*}{ TEP } & ND (0/4) & $\mathrm{ND}(1 / 4)$ & $\mathrm{ND}(0 / 4)$ & ND (0/4) & $\mathrm{ND}(0 / 4)$ & ND (0/4) & $\mathrm{ND}(0 / 4)$ & $\mathrm{ND}(0 / 4)$ \\
\hline & [ND] & [ND-0.15] & [ND] & [ND] & [ND] & [ND] & [ND] & [ND] \\
\hline \multirow{2}{*}{ TPP } & $\mathrm{ND}(0 / 4)$ & $1.08(4 / 4)$ & $\mathrm{ND}(0 / 4)$ & $0.79(4 / 4)$ & $\mathrm{ND}(0 / 4)$ & $0.55(2 / 4)$ & ND (0/4) & $0.99(3 / 4)$ \\
\hline & {$[\mathrm{ND}]$} & [0.96-1.95] & {$[\mathrm{ND}]$} & [0.64-1.18] & {$[\mathrm{ND}]$} & [ND-1.71] & {$[\mathrm{ND}]$} & [ND-1.42] \\
\hline
\end{tabular}

Note. The upper values show median concentration (detection rate) and the lower values show [concentration range]. All units are $\mathrm{ng} / \mathrm{m}^{3}$. ND means Not detected. 


\subsection{OPEs in Cigarettes}

Table 4 lists OPE concentrations in cigarette filters before and after smoking. TBP and TBEP were detected in all 16 samples before smoking. TBP was detected in two samples after smoking. Other OPEs were not detected either before or after smoking. The median concentration of TBEP, which was the largest OPE measured before smoking, was $344 \mathrm{ng} / \mathrm{g}$ (range: $190-1620 \mathrm{ng} / \mathrm{g}$ ). The median total OPE concentrations ranged from 356 to 2320 $\mathrm{ng} / \mathrm{g}$ before smoking, and from non-detectable levels to $448 \mathrm{ng} / \mathrm{g}$ after smoking.

Table 5 lists OPE concentrations in cigarette leaves. TBP and TBEP were detected in all 16 samples before smoking. TBP was detected in four samples after smoking. Other OPEs were not detected either before or after smoking. The median concentration of TBEP, which was the largest OPE measured before smoking, was 1870 ng/g (range: $329-2810 \mathrm{ng} / \mathrm{g}$ ). The median total OPE concentrations ranged from 516 to $2950 \mathrm{ng} / \mathrm{g}$ before smoking and from non-detectable levels to $1100 \mathrm{ng} / \mathrm{g}$ after smoking. OPE concentrations in cigarettes were higher in leaves than in filters.

Table 4. OPEs in cigarette filters

\begin{tabular}{|c|c|c|c|c|c|c|c|c|}
\hline & \multicolumn{2}{|c|}{ Brand A } & \multicolumn{2}{|c|}{ Brand B } & \multicolumn{2}{|c|}{ Brand C } & \multicolumn{2}{|c|}{ Brand D } \\
\hline & Before & After & Before & After & Before & After & Before & After \\
\hline \multirow{2}{*}{ TBEP } & $451(4 / 4)$ & $\mathrm{ND}(0 / 4)$ & $438(4 / 4)$ & $\mathrm{ND}(0 / 4)$ & $301(4 / 4)$ & $\mathrm{ND}(0 / 4)$ & $503(4 / 4)$ & $\mathrm{ND}(0 / 4)$ \\
\hline & [296-1620] & {$[\mathrm{ND}]$} & [275-807] & {$[\mathrm{ND}]$} & [190-485] & [ND] & [286-1440] & [ND] \\
\hline \multirow{2}{*}{ TBP } & & $\mathrm{ND}(1 / 4)$ & $308(4 / 4)$ & $\mathrm{ND}(0 / 4)$ & $259(4 / 4)$ & $\mathrm{ND}(0 / 4)$ & $363(4 / 4)$ & $\mathrm{ND}(1 / 4)$ \\
\hline & [49.3-728] & [ND-126] & [114-393] & [ND] & [166-596] & {$[\mathrm{ND}]$} & [118-390] & [ND-448] \\
\hline \multirow{2}{*}{ TCEP } & $\mathrm{ND}(0 / 4)$ & $\mathrm{ND}(0 / 4)$ & $\mathrm{ND}(0 / 4)$ & $\mathrm{ND}(0 / 4)$ & $\mathrm{ND}(0 / 4)$ & $\mathrm{ND}(0 / 4)$ & $\mathrm{ND}(0 / 4)$ & $\mathrm{ND}(0 / 4)$ \\
\hline & [ND] & {$[\mathrm{ND}]$} & [ND] & {$[\mathrm{ND}]$} & [ND] & {$[\mathrm{ND}]$} & {$[\mathrm{ND}]$} & [ND] \\
\hline \multirow{2}{*}{ TDCPP } & $\mathrm{ND}(0 / 4)$ & $\mathrm{ND}(0 / 4)$ & $\mathrm{ND}(0 / 4)$ & $\mathrm{ND}(0 / 4)$ & $\mathrm{ND}(0 / 4)$ & $\mathrm{ND}(0 / 4)$ & $\mathrm{ND}(0 / 4)$ & $\mathrm{ND}(0 / 4)$ \\
\hline & [ND] & [ND] & [ND] & [ND] & [ND] & [ND] & [ND] & [ND] \\
\hline \multirow{2}{*}{ TEHP } & $\mathrm{ND}(0 / 4)$ & $\mathrm{ND}(0 / 4)$ & $\mathrm{ND}(0 / 4)$ & $\mathrm{ND}(0 / 4)$ & $\mathrm{ND}(0 / 4)$ & $\mathrm{ND}(0 / 4)$ & $\mathrm{ND}(0 / 4)$ & $\mathrm{ND}(0 / 4)$ \\
\hline & [ND] & {$[\mathrm{ND}]$} & {$[\mathrm{ND}]$} & {$[\mathrm{ND}]$} & {$[\mathrm{ND}]$} & {$[\mathrm{ND}]$} & {$[\mathrm{ND}]$} & {$[\mathrm{ND}]$} \\
\hline \multirow{2}{*}{ TEP } & $\mathrm{ND}(0 / 4)$ & $\mathrm{ND}(0 / 4)$ & $\mathrm{ND}(0 / 4)$ & $\mathrm{ND}(0 / 4)$ & $\mathrm{ND}(0 / 4)$ & $\mathrm{ND}(0 / 4)$ & $\mathrm{ND}(0 / 4)$ & $\mathrm{ND}(0 / 4)$ \\
\hline & [ND] & [ND] & [ND] & {$[\mathrm{ND}]$} & [ND] & [ND] & [ND] & [ND] \\
\hline \multirow{2}{*}{ TPP } & $\mathrm{ND}(0 / 4)$ & $\mathrm{ND}(0 / 4)$ & $\mathrm{ND}(0 / 4)$ & $\mathrm{ND}(0 / 4)$ & $\mathrm{ND}(0 / 4)$ & $\mathrm{ND}(0 / 4)$ & $\mathrm{ND}(0 / 4)$ & $\mathrm{ND}(0 / 4)$ \\
\hline & [ND] & [ND] & [ND] & [ND] & [ND] & [ND] & {$[\mathrm{ND}]$} & {$[\mathrm{ND}]$} \\
\hline
\end{tabular}

Note. The upper values show median concentration (detection rate) and the lower values show [concentration range]. All units are ng/g. ND means Not detected. 
Table 5. OPEs in cigarette leaves

\begin{tabular}{|c|c|c|c|c|c|c|c|c|}
\hline & \multicolumn{2}{|c|}{ Brand A } & \multicolumn{2}{|c|}{ Brand B } & \multicolumn{2}{|c|}{ Brand C } & \multicolumn{2}{|c|}{ Brand D } \\
\hline & Before & After & Before & After & Before & After & Before & After \\
\hline \multirow{2}{*}{ TBEP } & $1970(4 / 4)$ & $\mathrm{ND}(0 / 4)$ & $1800(4 / 4)$ & $\mathrm{ND}(0 / 4)$ & $2620(4 / 4)$ & $\mathrm{ND}(0 / 4)$ & $707(4 / 4)$ & $\mathrm{ND}(0 / 4)$ \\
\hline & {$[1730-2560]$} & [ND] & {$[1310-2810]$} & {$[\mathrm{ND}]$} & [2110-2720] & {$[\mathrm{ND}]$} & [329-1130] & {$[\mathrm{ND}]$} \\
\hline \multirow{2}{*}{ TBP } & $52.4(4 / 4)$ & $\mathrm{ND}(1 / 4)$ & $45.6(4 / 4)$ & $\mathrm{ND}(1 / 4)$ & $62.4(4 / 4)$ & $\mathrm{ND}(1 / 4)$ & $122(4 / 4)$ & $\mathrm{ND}(1 / 4)$ \\
\hline & {$[20.5-60.5]$} & [ND-676] & [32.9-138] & [ND-440] & [30.1-185] & [ND-1100] & [22.0-186] & [ND-1010] \\
\hline \multirow{2}{*}{ TCEP } & $\mathrm{ND}(0 / 4)$ & $\mathrm{ND}(0 / 4)$ & $\mathrm{ND}(0 / 4)$ & $\mathrm{ND}(0 / 4)$ & ND (0/4) & $\mathrm{ND}(0 / 4)$ & $\mathrm{ND}(0 / 4)$ & ND (0/4) \\
\hline & [ND] & {$[\mathrm{ND}]$} & [ND] & [ND] & {$[\mathrm{ND}]$} & [ND] & [ND] & {$[\mathrm{ND}]$} \\
\hline \multirow{2}{*}{ TDCPP } & $\mathrm{ND}(0 / 4)$ & $\mathrm{ND}(0 / 4)$ & $\mathrm{ND}(0 / 4)$ & $\mathrm{ND}(0 / 4)$ & $\mathrm{ND}(0 / 4)$ & $\mathrm{ND}(0 / 4)$ & $\mathrm{ND}(0 / 4)$ & ND (0/4) \\
\hline & {$[\mathrm{ND}]$} & [ND] & [ND] & [ND] & {$[\mathrm{ND}]$} & {$[\mathrm{ND}]$} & {$[\mathrm{ND}]$} & {$[\mathrm{ND}]$} \\
\hline \multirow{2}{*}{ TEHP } & ND (0/4) & ND (0/4) & ND (0/4) & ND (0/4) & ND (0/4) & ND (0/4) & ND (0/4) & ND (0/4) \\
\hline & [ND] & [ND] & [ND] & [ND] & [ND] & [ND] & [ND] & [ND] \\
\hline \multirow{2}{*}{ TEP } & $\mathrm{ND}(0 / 4)$ & $\mathrm{ND}(0 / 4)$ & $\mathrm{ND}(0 / 4)$ & $\mathrm{ND}(0 / 4)$ & $\mathrm{ND}(0 / 4)$ & $\mathrm{ND}(0 / 4)$ & $\mathrm{ND}(0 / 4)$ & $\mathrm{ND}(0 / 4)$ \\
\hline & [ND] & [ND] & [ND] & [ND] & [ND] & [ND] & {$[\mathrm{ND}]$} & [ND] \\
\hline \multirow{2}{*}{ TPP } & ND (0/4) & $\mathrm{ND}(0 / 4)$ & $\mathrm{ND}(0 / 4)$ & $\mathrm{ND}(0 / 4)$ & $\mathrm{ND}(0 / 4)$ & $\mathrm{ND}(0 / 4)$ & $\mathrm{ND}(0 / 4)$ & $\mathrm{ND}(0 / 4)$ \\
\hline & {$[\mathrm{ND}]$} & [ND] & {$[\mathrm{ND}]$} & [ND] & {$[\mathrm{ND}]$} & {$[\mathrm{ND}]$} & {$[\mathrm{ND}]$} & {$[\mathrm{ND}]$} \\
\hline
\end{tabular}

Note. The upper values show median concentration (detection rate) and the lower values show [concentration range]. All units are $\mathrm{ng} / \mathrm{g}$. ND means Not detected.

\subsection{Gas-Particle Partitioning of OPEs}

Gas-particle partitioning is one of the important factors that affect the fate of semi-volatile organic compounds in environments (Yamasaki, et al., 1982; Pankow, 1987; Lohman et al., 2000). Gas-particle partitioning of OPEs in air is presented here using the gas-particle partition coefficient $\left(\mathrm{Kp}, \mathrm{m}^{3} / \mu \mathrm{g}\right)$ calculated for OPEs determined simultaneously in the gas and particulate phases:

$\mathrm{Kp}=(\mathrm{F} / \mathrm{TSP}) / \mathrm{A}$

Where $F$ is the particulate-phase concentration of OPEs $\left(\mathrm{ng} / \mathrm{m}^{3}\right), A$ is the gas-phase concentration $\left(\mathrm{ng} / \mathrm{m}^{3}\right)$, and TSP is the total suspended particulate concentration $\left(\mu \mathrm{g} / \mathrm{m}^{3}\right)$. The mean values of $\log \mathrm{Kp}$ for the OPEs detected in both the gas and particulate phases $(n \geq 5)$ ranged from -1.79 (TCEP) to -2.24 (TPP) after smoking.

The partition coefficient $\mathrm{Kp}$ for a given compound was correlated with its subcooled liquid vapor pressure ( $\mathrm{PL}^{\circ}$, Torr) using the following equation (Liang et al, 1996; Tsapakis et al., 2005; Akyüz, 2010):

$\log \mathrm{Kp}=\mathrm{mr} \times \log \mathrm{PL}^{\circ}+\mathrm{br}$

Where $\mathrm{mr}$ and br are the slope and the intercept of the regression line, respectively. The relationships between $\operatorname{logKp}$ and $\log \mathrm{PL}^{\circ}$ before and after smoking are shown in Figure 1. Median values of the measured data summarized by Sühring et al. (2016) were used as the $\mathrm{PL}^{\circ}$ of OPEs. The dotted line represents the relationship between $\operatorname{logKp}$ and $\log \mathrm{PL}^{\circ}$ for alkanes by Liang et al. (1996). The points for low-log $\mathrm{PL}^{\circ}$ OPEs such as TPP lie near the correlation line for alkanes, but the points for high-log $\mathrm{PL}^{\circ} \mathrm{OPEs}$ such as TBP and TCEP lie far from the correlation line. High-log $\mathrm{PL}^{\circ}$ OPEs were adsorbed to particles in air more readily than alkanes. These findings show that the low-log $\mathrm{PL}^{\circ} \mathrm{OPEs}$ tend to exist in the gas phase, and the high-log $\mathrm{PL}^{\circ} \mathrm{OPEs}$ tend to exist in the particulate phase.

\subsection{OPE Emission Characteristics during Smoking}

The emission characteristics for TBP, TBEP, TCEP, and TPP are described here because these OPEs were detected frequently in this study. Figure 2 presents the median contents of these OPEs in air and cigarettes before and after smoking. Levels in air were calculated as the median concentrations multiplied by $24 \mathrm{~m}^{3}$ for a sample collected before smoking and by $66 \mathrm{~m}^{3}$ for a sample collected after smoking. Levels in cigarettes were calculated as the median of the cigarette filter concentrations multiplied by the weights times two, plus the median of the cigarette leaf concentrations multiplied by the weights times two. The reason for multiplying by two was that 
two cigarettes of each brand were smoked during the experiments. Non-detectable levels were treated as zero. The median contents of OPEs before smoking were $223 \mathrm{ng} / \mathrm{room}$ per cigarette (TBP), $2130 \mathrm{ng} / \mathrm{room}$ per cigarette (TBEP), and $56.2 \mathrm{ng} /$ room for particulate-phase TCEP. Median contents after smoking, however, were much higher (e.g., $348 \mathrm{ng} /$ room for particulate-phase TBP and $4260 \mathrm{ng} /$ room for particulate-phase TBEP). Table 6 lists the correlation coefficients for the relationships between the particulate-phase OPEs after smoking. TBP and TCEP concentrations tended to increase as TBEP concentrations increased. TPP concentrations tended to increase as TCEP concentrations increased. These findings imply that TBP and TBEP concentrations in cigarettes increased with the combustion reaction, and some were transformed to other OPEs and then emitted into air. TBP and TBEP in cigarettes probably affect the production of the OPEs during smoking.

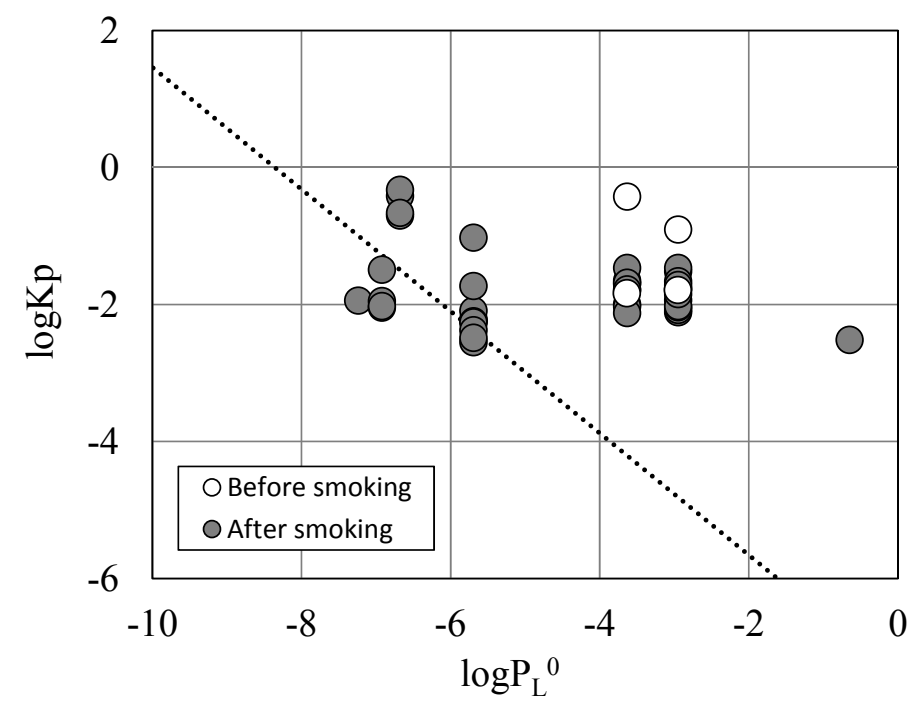

Figure 1. Relationships between $\log \mathrm{Kp}$ and $\log \mathrm{PL}^{\circ}$ before and after smoking

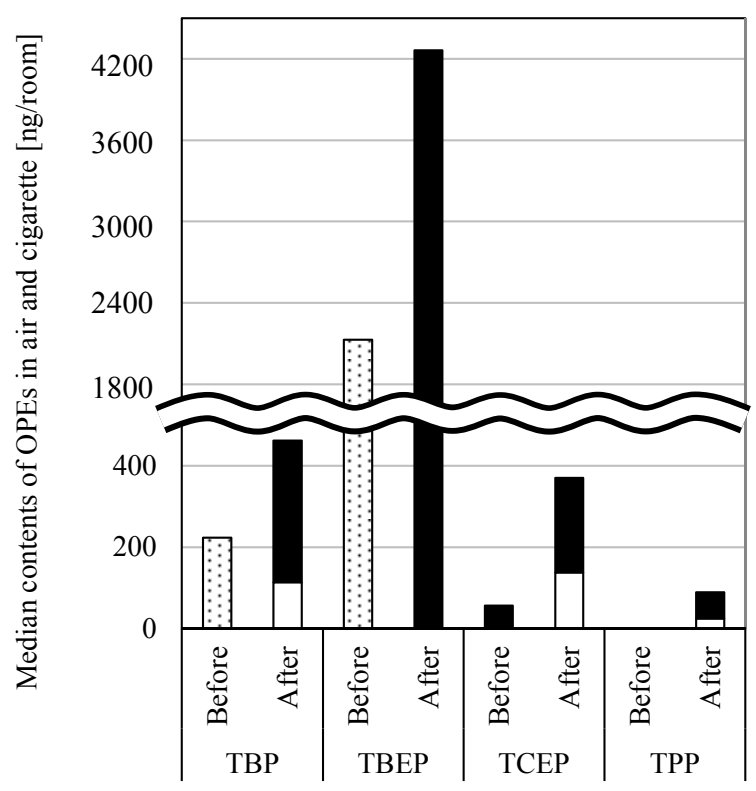

Figure 2. Median contents of OPEs in air and cigarettes before and after smoking

Note. Before indicates before smoking, and After indicates after smoking. Stippled bars, open bars, and solid bars show contents for OPEs in cigarettes, gas-phase OPEs in airs, and particulate-phase OPEs in airs, respectively. 
Table 6. Pearson Coefficients for Correlations among the detected particulate-phase OPEs in airs after smoking

\begin{tabular}{lccc}
\hline & TBEP & TBP & TCEP \\
\hline TBP & 0.421 & & \\
TCEP & 0.251 & $0.531^{*}$ & \\
TPP & -0.096 & 0.010 & 0.365 \\
\hline
\end{tabular}

Note. $*$; $<0.05$.

\section{Conclusions}

The OPE concentrations in four brands of cigarettes and their sidestream smoke were examined, and the characteristics of OPE formation during smoking were investigated from the OPE mass balance in the cigarettes and smoke. The results are summarized as follows.

(1) OPE levels in sidestream cigarette smoke before and after smoking were determined in an air sampling room with an approximate volume of $66 \mathrm{~m}^{3}$. The medians of total gas-phase and particulate-phase OPE concentrations after two cigarettes were smoked were $4.77 \mathrm{ng} / \mathrm{m}^{3}$ and $74.2 \mathrm{ng} / \mathrm{m}^{3}$, respectively, and the concentrations were higher after smoking. Median total OPE increases in the air samples during smoking were $56.2 \mathrm{ng} /$ cigarette for gas-phase OPEs and $2360 \mathrm{ng} /$ cigarette for particulate-phase OPEs.

(2) The points for high-log $\mathrm{PL}^{\circ}$ OPEs such as TBP and TCEP lie far from the correlation line between gas-particle partition coefficients $(\mathrm{Kp})$ and the subcooled liquid vapor pressures $\left(\mathrm{PL}^{\circ}\right)$ for alkanes. High-log $\mathrm{PL}^{\circ}$ OPEs were adsorbed to particles in air more readily than alkanes.

(3) OPE levels in cigarettes before and after smoking were determined. Only TBP and TBEP were detected. The medians of total OPE concentrations before smoking in cigarette filters were $780 \mathrm{ng} / \mathrm{g}$ and $1900 \mathrm{ng} / \mathrm{g}$, respectively; concentrations were lower after smoking. Median total OPE decreases in cigarettes during smoking were $1200 \mathrm{ng}$ per cigarette.

(4) The combustion reaction increased TBP and TBEP levels in cigarettes, and particulate-phase TBEP in air appeared to influence the production of TBP, TCEP, and TPP. TBP and TBEP in cigarettes likely affect the production of TBP, TBEP, TCEP and TPP in air during smoking.

\section{Acknowledgments}

The author would like to thank Kindai University for providing the grant to complete this research. The author acknowledges the assistance given by Tsuyoshi Yata and Naoto Ozaki, and thank Dean Meyer, PhD, ELS from Edanz Group (www.edanzediting.com/ac) for editing a draft of this manuscript.

\section{References}

Akyüz, M., \& Çabuk, H. (2010). Gas-particle partitioning and seasonal variation of polycyclic aromatic hydrocarbons in the atmosphere of Zonguldak, Turkey, Science of the Total Environment, 408, 5550-5558. https://doi.org/10.1016/j.scitotenv.2010.07.063

Andresen J. A., Grundmann A., \& Bester K. (2004). Organophosphorus flame retardants and plasticisers in surface waters. Science of the Total Environment, 332, 155-166. Retrieved from https://ac.els-cdn.com/S0048969704003316/1-s2.0-S0048969704003316-main.pdf?_tid=21edd8b9-cd84-44 72-a251-9f5f11621e90\&acdnat=1527648076_86b0c1464194cd8023e42eb8e1712703

Brommer, S., Harrad, S., Van den Eede, N., \& Covaci, A. (2012) Concentrations of organophosphate esters and brominated flame retardants in German indoor dust samples. Journal of Environmental Monitoring, 14, 2482-2487. Retrieved from http://pubs.rsc.org/en/content/articlepdf/2012/EM/C2EM30303E

Chung, H. W., \& Ding, W. H. (2009). Determination of organophosphate flame retardants in sediments by microwave-assisted extraction and gas chromatography-mass spectrometry with electron impact and chemical ionization. Analytical and Bioanalytical Chemistry, 395, 2325-2334. Retrieved from https://link.springer.com/article/10.1007/s00216-009-3139-4

European Chemicals Agency. (2009). Inclusion of substances of very concern in the candidate list.

Fries, E., \& Mihajlovic, I. (2011). Pollution of soils with organophosphorus flame retardants and plasticizers. Journal of Environmental Monitoring, 13, 2692-2694. Retrieved from http://pubs.rsc.org/en/content/articlepdf/2011/EM/C1EM10538H 
Gosselin, R. E., Smith, R. P., \& Hodge, H. C. (1984). Clinical Toxicology of Commercial Products (5th ed.). Baltimore, II-302.

Kawagoshi, Y., Fukunaga, I., \& Itoh, H. (1999). Distribution of organophosphoric acid triesters between water and sediment at a sea-based solid waste disposal site. Journal of Material Cycles and Waste Management, 1, $53-61$.

Lai, S., Xie, Z., Song, T., Tang, J., Zhang, Y., Mi, W., ... Ebinghaus R. (2015). Occurrence and dry deposition of organophosphate esters in atmospheric particles over the northern South China Sea. Chemosphere, 127, 195-200. Retrieved from https://ac.els-cdn.com/S0045653515001174/1-s2.0-S0045653515001174-main.pdf?_tid=171c4284-0dfd-41 85-9a5e-ec300d8181a7\&acdnat=1527647019_a940c25f89809ab81c2526fb0164e790

Liang, C., \& Pankow, J. F. (1996). Gas/particle partitioning of organic compounds to environmental tobacco smoke: partition coefficient measurements by desorption and comparison to urban particulate material. Environmental Science and Technology, 30, 2800-2805. Retrieved from https://pubs.acs.org/doi/pdf/10.1021/es960050x

Lohmann, R., Harner, T., Thomas, G. O., \& Jones, K. C. (2000). A comparative study of the gas-particle partitioning of PCDD/Fs, PCBs, and PAHs, Environmental Science and Technology, 34, 4943-4951. Retrieved from https://pubs.acs.org/doi/pdf/10.1021/es9913232

Marklund, A., Andersson, B., \& Haglund, P. (2005). Organophosphorus flame retardants and plasticizers in Swedish sewage treatment plants. Environmental Science and Technology, 39, 7423-7429. Retrieved from https://pubs.acs.org/doi/pdf/10.1021/es0510131

Pankow, J. F. (1987). Review and comparative analysis of the theories on partitioning between the gas and aerosol particulate phases in the atmosphere. Atmospheric Environment, 21, 2275-2283. https://doi.org/10.1016/0004-6981(87)90363-5

Salamova, A., Hermanson, M. H., \& Hites, R. A. (2014). Organophosphate and halogenated flame retardants in atmospheric particles from a European arctic sites. Environmental Science and Technology, 48, 6133-6140. Retrieved from https://pubs.acs.org/doi/pdf/10.1021/es500911d

Shimazu, H., Shibata, T., \& Horie, T. (2013). Bioaccumulation characteristics of organophosphoric acid triesters and polycyclic aromatic hydrocarbons in Phragmites. Journal of Water and Environment Technology, 11, 287-297. https://doi.org/10.2965/jwet.2013.287

Shimazu, H. (2016). Determination of Organophosphate Esters in Cigarettes and Cigarette Smoke. Modern Environmental Science and Engineering, 2(12), 792-799. Retrieved from http://www.academicstar.us/UploadFile/Picture/2017-9/201792232818615.pdf

Sühring, R., Wolschke, H., Diamond, M. L., Jantunen, L. M., \& Scheringer, M. (2016). Distribution of organophosphate esters between the gas and particle phase-model predictions vs measured data. $\begin{array}{lllll}\text { Environmental Science } \quad \text { and } & \text { 6echnology, }\end{array}$ https://pubs.acs.org/doi/pdf/10.1021/acs.est.6b00199

Tsapakis, M., \& Stephanou, E. G. (2005). Polycyclic aromatic hydrocarbons in the atmosphere of the Eastern Mediterranean. Environmental Science and Technology, 39, 6584-6590. Retrieved from https://pubs.acs.org/doi/pdf/10.1021/es0505321

Townsend Solutions. (2012). Plastic Additives 8 Global Market Study.

TÜV Rheinland Group. (2013). US Tightens Requirements On Flame Retardants For Children Products.

Van der Veen, I., \& de Boer, J. (2012). Phosphorus flame retardants: properties, production, environmental occurrence, toxicity and analysis. Chemosphere, 88, 1119-1153. Retrieved from https://ac.els-cdn.com/S0045653512004353/1-s2.0-S0045653512004353-main.pdf?_tid=7915f8c0-4f21-40f a-b04a-95b706e6ef77\&acdnat $=1527645888 \_1$ fla608b462d44e3330186bd578a3ed0

WHO. (1991a). Tributyl phosphate, Environmental Health Criteria 112.

WHO. (1991b). Triphenyl phosphate, Environmental Health Criteria 111.

WHO. (1998). Flame Retardants: Tris(chloropropyl) phosphate and tris(2-chloroethyl) phosphate. Environmental Health Criteria 209.

WHO. (2000). Flame Retardants: Tris(2-butoxyethyl) phosphate, tris(2-ethylhexyl) Phosphate and tetrakis 
(hydroxymethyl) phosphonium salts. Environmental Health Criteria, 218.

Yamasaki, H., Kuwata, K., \& Miyamoto, H. (1982). Effects of ambient temperature on aspects of airborne polycyclic aromatic hydrocarbons. Environmental Science and Technology, 16, 189-194. https://doi.org/10.1021/es00098a003

\section{Copyrights}

Copyright for this article is retained by the author(s), with first publication rights granted to the journal.

This is an open-access article distributed under the terms and conditions of the Creative Commons Attribution license (http://creativecommons.org/licenses/by/4.0/). 